\title{
Doğumunun 400. Yılında Halvetî Şeyhi Muhammed Askerî ve Na'tları
}

\section{Muhammed Askeri, the Sheikh of Halveti and his Na'ts on the $400^{\text {th }}$ Anniversary of his Birth}

\author{
Doç. Dr. Mehmet SARI
}

$\ddot{O} z$

Bu araştırmada XVII. yüzyıl Halvetî tarikatına mensup mutasavvıf şairlerden Askerî'nin hayatı, edebî kişiliğgi ve divanının nüshaları üzerinde durularak, divanın yazma nüshalarından hareketle edisyon kritiği yapılan na'tlar verilecektir. Asıl adı Muhammed/Mehmed olan Askerî, aslen Kütahyalı olup 1621'de doğmuştur. Askerî, Elmalılı Ümmî Sinan'a intisap etmiş ve onun yanında yetişmiştir. Afyonkarahisar'da Halvetî şeyhi olarak 40 yıla yakın hizmette bulunmuş ve 1693 'te burada vefat etmiştir. Kabri Afyonkarahisar'dadır. Bilinen 12 yazma nüshası bulunan, aruz ve hece ölçüsüyle yazdığı tasavvufî şiirlerden meydana gelen 4000 beyitlik divanı vardır. Bu şiirlerden olan na‘tlar divanda önemli bir yer tutar.

Anahtar Kelimeler: Askerî, Askerî divanı, Halvetî, na‘t

Makale Türü: Araştırma

\begin{abstract}
In this research, as asserting on one of the poets that was a member of 17th Century Halveti trend, sophistic Askeri's life, literary figure and divan manuscripts of him, in terms of divan's handwritting manuscripts, criticized their edition perpective na'ts are given. Askeri whose real name was Muhammed's home city was Kutahya and he was born on 1621. Askeri became affiliated with Elmalili Ummu Sinan and raised in his leadership. As seyh of Halveti, he served in Afyonkarahisar approximately 40 years and died in Afyonkarahisar in 1693. His tomb is in Afyonkarahisar. We have a divan of him of which there is 12 handwritten manuscripts and which has 4000 verses and made of sufistic poetries and written with both aruz and syllable measure. $\mathrm{Na}$ 'ts that is one these poetries has a significant role in the divan.
\end{abstract}

Keywords: Askeri, Askeri’s divan, Halveti, na‘t

Paper Type: Research

\footnotetext{
${ }^{1}$ Afyon Kocatepe Üniversitesi, Fen Edebiyat Fakültesi, msari@aku.edu.tr

Atıf için (to cite): Soyad, A. (2021). Doğumunun 400. Yılında, Halvetî Şeyhi Muhammed Askerî ve Na 'tları. Afyon Kocatepe Üniversitesi Sosyal Bilimler Dergisi, 23(3), 888-912.
} 


\section{Giriş}

Zengin bir kültüre, tarihe ve edebiyata sahip olan Kütahya, Osmanlı döneminde Mevleviliğin ve Halvetîliğin önemli merkezlerinden biri olmuştur. Osmanlının bu eğitim, öğretim, edebiyat ve sanat ocaklarında önemli şahsiyetler yetişmiş; bu şahsiyetler yaşayışları, öğretileri ve yazdıkları eserleriyle manevi yönden sağlam bir toplum oluşmasına önemli katkı sağlamışlardır. İşte bu şahsiyetlerden biri, Kütahyalı Halvetî şeyhi Gülaboğlu Muhammed Askerî' dir. Bu çalışmamızda, doğumunun 400. sene-i devriyyesinde Askerî'nin hayatından, eserlerinden ve edebi şahsiyetinden söz edilecek; 4000 beyitlik divanındaki aruz ve hece vezniyle, farklı nazım şekilleriyle yazılmış "Na't'ları üzerinde durulacaktır.

\section{Adı, Mahlası, Lakâbı ve Ailesi}

Askerî, asıl adı Muhammed/ Mehmed (Tahir, 1333, s.308; Tuman, sıra No: 2864; Ergun, 1936, s. 508) olup XVII. yüzyıl mutasavvıf şairlerindendir. Kütahya'nın Altıntaş ilçesine bağlı Zemme köyünde dünyaya geldi (Tuman, sira No: 2864; Uraz, 1939; s. 31; Aygen, 1979). Bazı kaynaklarda doğum tarihi, pîrdaşı Niyazî Mısrî’nin doğum tarihi olan 1617-1621 yılları civarında bir tarih olabileceği belirtilerek 1621 olduğu kabul edilir (Aygen, 1979, s. 10; Yazıcıoğlu, 1995, s 265). Babasının adı "Gülâbî" (Sarı, 2000, s. 515) ye atfen "Gülaboğlu" (Tahir, 1333, s. 308; Tuman, sira No: 2864; Aygen, 1979, s. 9; Ünver, 1991, s. 491) lâkabıyla tanınan, bazı kaynaklarda "Çalık Muhammed Ağa" (Aygen, 1979, s. 9) olarak zikredilen Askerî Afyonkarahisar' da bir sayg1 ve sevgi ifadesi olarak "Askerî Baba", "Askerî Dede" (Bak1, 1942, s. 21; Aygen, 1979, s 7; Sar1, 2007, s 2) hitabiyla anılır. Askerî şiirlerinde "Muhammed/Mehemmed", "Muhammed Hân", "Dervîş Askerî", "Askerî Derviş" şeklinde mahlasını, ismini ve lâkabını kullanır:

"Lâ-mekân iklîminün şehrinde nûr-ı mübhemüz

Bil Gülâboğlı Muhammed 'dür bu yerde adımuz" (Sar1, 2016, s, 383)

**

"Sordum adın didi adunla adım durur adaş

Hamdüli'llâh bildim adın kim Muhammed Hân imiş" (Sarı, 2016, s. 305)

**

"Hamdüli'llâh çok şükür bî-çâre Dervîş 'Askerî

Âsitân-ı devletinde bir gedâdur bir gedâ"'(Sarı, 2016, s. 186)

$* *$

“'Askerî Derviş'e virdi "men 'aref”' sirrın haber

Okıdup 'ilm-i ledünnîden sebak pîr-i mügân”'(Sar1, 2016, s 386)

Kaynaklarda, ailesi hakkında fazla bilgi bulunmayan Askerî’nin, Aygen'in verdiği bilgilerden (Aygen, 1979, s. 9) hareketle doğduğu Zemme (Çayırbaşı) köyünde yaşayan "Bayram" soyadlı aileye ulaşılmış ve bu aileden 1946 doğumlu Halil Bayram'dan edinilen bilgilerden hareketle Askerî’nin şeceresi çıkarılmıştır (Sarı, 2016, s 22).

\section{Tahsili, Tarikatı, Pîri ve Seyahatleri}

İlk tahsiline babası Gülâbî’nin yanında Zemme köyündeki medresede başlayan Askerî, temel eğitimini aldıktan sonra Kütahya'ya gidererek medrese öğrenimini burada tamamlamış (Aygen, 1979, s. 10) ve 1056/1646'de Halvetî şeyhi ve şairi Elmalılı Ümmî Sinan'a (öl. 1657) intisap ederek (Güner, 1967, s. 66) "Beş Er" (Aygen, 1979, s. 10; Tatçı ve Kurnaz, 1999, s. 25) diye tanınan halifelerinden biri olarak Ümmî Sinan'ın yanında yetişerek hocasından feyiz ve icazet almıştır (Ergun, 1936, s. 508; Aygen, 1979, s. 11; Erdoğan, 1998, s. 203). 
Askerî, tahsilini geliştirmek için bir müddet İstanbul'da bulunur, buradan Afyon'a müderris olarak görevlendirilir (Bak1, 1942, s. 22; Aygen, 1979, s. 26). H.1065/M.1655 tarihinde, "Taş Medrese" olarak anılan, Selçuklulardan kalma Afyon'un ilk ilim müessesesi "Hisarardı Alâeddin" Medresesi'ne atanır (Sarı, 2016, s. 21). Bu medresede 30-40 yıl müderrislik yapan (Aygen, 1979, s. 28; Yazıcıoğlu, 1995, s. 265) Askerî, Afyon halkı tarafından çok sevilmiştir (Gönçer, 1991, s. 122). Askerî, tahsilini ve olgunluğunu geliştirmek için bir süre Şam ve Buhara gibi ilim merkezlerinde de bulunur (Bak1, 1942, s. 22; Ünver, 1991, s. 491).

Halvetiyye tarikatının üçüncü ana kolu Ahmediyye şubesine bağlı olan Askerî, bağlı bulunduğu tarikatından ve "mürşidim", "kutb-1 tâcü’l-'âşıkîn", "bürhân", "pâdişâh" gibi ifadelerle zikrettiği pîri Sinan Ümmî’ den şiirlerinde çokça söz eder:

"Mürşidümdir Pîr Sinân Ümmî 'azîzüm 'aşkına

Pâdişâhum bizi bizden lutf idüp itme su 'âl' (Sarı, 2016, s. 344)

**

“'Askerî ider Hâlikun ihsânına bin bin şükür

Ol kutb-ı tâcü'l- 'âşılkin Pir Ümmî Sinân bizdedür”' (Sar1, 2016, s. 271)

**

"İhsânina Hakkun şükür eyler dem-â-dem 'Askerî

Ümmî Sinân gibi ulu bürhânumuz vardur bizüm” (Sar1, 2016, s. 351)

"Biz tarîk-i halvetîyüz 'ilm-i hikmet bizdedür

Bezm-i 'aşka sohbetiyüz bâki sohbet bizdedür”' (Sarı, 2016, s. 238)

**

"Hakîkat 'arif ü ma 'rûf tarîk-i halvetîlerdür

Kemâlu'llâh ile mevsûf tarîk-i halvetîlerdür"' (Sar1, 2016, s. 257)

\section{Vefatı ve Kabri}

Muhammed Askerî, 40 yıla yakın hizmet ettiği Afyonkarahisar'da H.1104/M.1693'te vefat eder (Aygen, 1979, s. 28; Ünver, 1991, s. 491) ve uzun yıllar müderrislik yaptı̆̆ Hisarard1 Medresesi'nin karşısındaki Çavuşlar Sultan Kabristanı'na defnedilir (Güner, 1967, s. 67; Gönçer, 1991, s. 123). Adı geçen kabir sonraki zamanlarda başka yere taşınır. Bugün Askerî̀nin kabri Afyonkarahisar Kalesi'nin batı tarafında Çavuşbaş Mahallesi Göksu Sokak'ta 1. nolu Sağlık Ocağı'nın karşısındaki yol üzerindedir (Sarı, 2007, s. 20).

\section{Edebî Kişiliği}

Halvetî şeyhi Muhammed Askerî âlimliği yanı sıra mutasavvıf bir şairdir. Şiirleri incelendiğinde, Yunus Emre, Nesimî, Fuzûlî, Ümmî Sinan ve Niyazî Mısrî’nin tesirinde kaldığ görülür (Sarı, 2016, s. 66). Bu konuda Edip Ali Bak1 (1942, s. 24) "Şair, bu şiirlerile Türk şairi Nesimî’nin izinde ve gölgesinde yürümeğe çalışmaktadır. Şaire birinci safa yakın yer vermekte, içinin aşk ve şevk ateşi her misrainda kendini göstermektedir" der.

Askerî, şiiri bir vasıta olarak görmüş̧ İslâm'ın, tasavvufun, bağlı bulunduğu Halvetîliğin özünü şiir vasıtasıyla anlatmıştır. Kendi ifadesiyle nazmı, vahdet sırrının şerhi ve Kur'ân'ın tefsiri durumundadır:

\section{"Nazmımuz na 't-l îlâhî sırr-ı vahdet şerhidür}

Tâb-ı nâ-mevzûn olanlar anlamaz eş 'ârımuz”' (Sarı, 2016, s. 279) 
"Şi 'rimüz tefsîr-i Kur' ân âyet-i Rahmânîdür

Sirr-ı vahdet söylerüz bürhânımuz tevhîd-i zât" (Sarı, 2016, s. 215)

Mutasavvıf bir şair olan Askerî dinî ve tasavvufî şiirler yazmış; ilâhî ve ruhânî bir eda taşıyan bu şiirlerinde bağlı bulunduğu Halvetî tarikatının düşünce sistemini yaymaya çalışmıştır. Askerî’nin şiirleri incelendiğinde didaktik şiirlerine klyasla lirik şiirlerinin daha sade olduğu görülecektir (Sarı, 2000, s. 515). Aruzla yazdığı şiirlerinde, yakın dostu Niyazî Mısrî gibi Nesîmî’nin ve Fûzûlî'nin, heceyle yazdığı şiirlerinde ise Yunus Emre'nin tesiri altında kaldığı görülür (Sarı, 2016, s. 45).

Askerî şiirlerinde, dinî ve tasavvufî konuların ifade edilişinde kullanılan tür ve şekilleri tercih etmiş, fazla çeşide yer vermemiştir. Hem aruz hem heceyle yazan Askerî’nin dili, aynı dönemde yaşamış birçok şaire göre sade ve akıcı olup, şiirlerde arkaik kelimeler, halk söyleyişleri sıkça kullanılmış ve dönemin dil özellikleri yansıtılmıştır.

\section{Dîvânının Nüshaları}

Muhammed Askerî dîvânnın 10'dan fazla yazma nüshası bulunmaktadır. Yarım asra yakın bir zamanda Afyonkarahisar'da yazılan 4000 civarında beyitten oluşan divanın 9 yazma nüshadan hareketle oluşturulan Tenkitli Metni yayımlanmıştır (Sarı, 2007; 2016). Tasavvufî manzumelerden oluşan divanda, münacat, na't, mehdiye, murabba, muhammes, müseddes, müsebba gibi manzumelerle Yunus Emre tesiriyle yazılmış ilâhîler bulunmaktadır (Aygen, 1979, s. 38; Ünver, 1991, s. 492; Sar1, 2016, s. 46).

Askerî Muhammed-Hayatı, Eserleri, Edebî Kişiliği-Dîvânının Tenkitli Metni adlı çalışmada genişçe tanıtılan Askerî Divanının başlıca nüshalarının bilgileri şöyledir: 06 Ankara Milli Kütüphane Yz. Nu.:F.B.248; 06 Ankara Milli Kütüphane Yz. Nu.: A.1896; 06 Ankara Milli Kütüphane Yz. Nu.:F.B.285; Konya Mevlânâ Müzesi İhtisas Kütüphanesi Yz. Nu.:2400; Süleymaniye Kütüphanesi Hacı Mahmut Efendi Böl (Yahya Ef. Kısmı). Nu.:3374; Süleymaniye Kütüphanesi Haşim Paşa Böl. Nu.:94/1; İstanbul Üniversitesi Kütüphanesi Türkçe Yazma Eserler Yz. Nu.:137/3; İstanbul Üniversitesi Kütüphanesi Türkçe Yazma Eserler Yz. Nu.: 2806; 06 Ankara Mill. Ktb. Yz. F.B.627/1 (Sar1, 2007, s. 58-64).

\section{6. "Na't'ları}

Na't genel itibariyle Hz. Muhammed'i övmek için yazılan şiir olmakla beraber Dört halife, Hz. Hasan, Hz. Hüseyin, Hz. Abbas, Ebû Hanife, İmam Şâfî, İmam Mâlik, İmam Ahmet, İmam Buharî, İmam Müslim gibi din ve tarikat büyükleri için yazılmış şiirler için de kullanılır. Hz. Peygamber'i övmek için yazılanlar Nat-1 Şerif, Na't-1 Nebevî, Na't-1 Peygamberî, Na‘t-1 Resûl; Dört halife için yazılanlar ise Na't-1 Çâr-Yâr adını alır.

Na'tlar, kaynaklarda yazılan yaygın bir kanaate göre divanların başında tevhid ve münacattan sonra yer alır ise de divanların içinde mesnevi, kaside, gazel, müstezat, kıt'a, rubaî, tuyuğ murabba, muhammes, müseddes, terkib-i bend, terci-i bend gibi şekillerle yazılmış olarak da görülür (Canım, 2014, s. 176).

Hz. Peygamber'in peygamberliğini, mucizelerini, yaşadığı sıkıntıları, içten gelen samimi hislerle, manzum veya mensur olarak dile getiren na'tlar, aynı zamanda Hz. Peygamber'den şefaat dilemek ve ona yalvarmak için yazıldıkları için özentili ve süslü ifadelerden kaçınılarak sade bir üslupla kaleme alınmıştır. Lirizmin hâkim olduğu bu tür eserler hitâbî bir üslupla yazılmışlardır (İsen, 2011, s. 260; Canım, 2014, s. 176).

Bilindiği gibi divan edebiyatımız "belirgin olarak dinî bir karekter" taşır ve "dokusu itibarıyla İslâmî bir edebiyattır". Bilhassa tevhid, münacat, na't gibi dinî muhtevalı şiirlerde şairler, fikir ve görüşlerini kuvvetlendirmek için âyetlere ve hadislere yer verirler. Âyetler bütünüyle ele alınabildiği gibi, "nâkıs", "lafzen", "mânen" de verilebilir (Yeniterz, 1993, s. 91). 
$\mathrm{Na}^{\text {'t }}$ türündeki eserlere ilk kez-na't kelimesi kullanılmadan-methiye ifadesiyle Arap edebiyatında rastlanır. Acem edebiyatında özellikle mesnevilerin ve divanların içinde görülen na'tlar Türk edebiyatını da etkiler ve Türk edebiyatında da na'tlar İslamiyet'in kabulüyle birlikte eserlerin içinde bölüm olarak görülmeye başlar. Türk edebiyatında "na't'lar, Sinan Paşa'nın Ma'rifetnâme ve Tazarrunâme adlı eserlerinde görüldüğü gibi mensur olarak da yazılmakla birlikte daha çok manzum olarak kaleme alınmışlardır. Yusuf Has Hâcip, Edib Ahmed Yüknekî, Ahmed Yesevî ve Ali Şîr Nevâyi'nin gelişmesine öncülük ettiği "na't" Âşık Paşa, Şeyhoğlu Mustafa, Fuzûlî gibi şairlerde görüleceği gibi mesnevi nazım şekliyle yazılmıştır (İsen, 2011, s. 260; Canım, 2014, s. 176).

Edebiyatımızın her alanında na't yazılmıştır. Türk tasavvuf edebiyatından Yunus Emre, Hacı Bayram Veli, Kaygusuz Abdal, Eşrefoğlu, Dede Ömer Ruşeni, Aziz Mahmut Hüdâyî, Niyâzî Mısrî, Askerî, Erzurumlu İbrahim Hakkı; Divan edebiyatından Ahmedî, Zâtî, Nev‘î, Nazîm, Fuzûlî, Nef'î, Nâbî, Şeyh Gâlib; Yeni Türk edebiyatından Ziya Paşa, Muallim Nâcî, Recâizâde Mahmut Ekrem, Mehmet Âkif, Yahya Kemal Beyatlı, Arif Nihat Asya, Necip Fazıl Kısakürek na't yazan şairlerimizden bazılanıdır.

XVII. yüzyıl şairlerinden Muhammed Askerî de değişik nazım şekilleriyle birçok na't yazmıştır. Hz. Peygamber Efendimizi övmek amaciyla yazdığı "Na't-1 şerif" manzumeleri yanında Hz. Ali'nin medhine dair yazdığ1 "Na't-1 Ali" manzumesi de mevcuttur. Bu na thlarda Askerî'nin içten gelen sıcak ve samimi ifadeleri, Peygamber Efendimize yalvarışı dikkat çeker. Sanat endişesinden uzak olarak yazılan bu na'tlardaki dilin-dini terimler ve kavramlar dışındaşairin diğer şiirlerine kıyasla daha sade olduğu söylenebilir. Genellikle kaside nazım şekliyle yazılan "na't"lar, Askerî Divanı'nda gazel, murabba, müseddes, tercî'-i bend gibi farklı şekillerle yazılmış olarak görülür.

Muhammed Askerî, sade bir halk söyleyişiyle yazdığı na'tlarında, içten gelen samimi bir yakarışla, çaresizliğini ve zayıflığını dile getirir ve Peygamber Efendimiz Hz. Muhammed Mustafa'nın ve Hz. Ali Efendimizin evsafından söz eder. "Ben za'îfe kıl şefâ'at" yalvarışı ve "Yâ Muhammed Mustafâ" hitabıyla "nûr-1 hidâyet" olan Peygamber Efendimizden "inâyet" ister. Ağlayarak kapısına geldiğini söyler ve kendisini reddeylememesi için yalvarışta bulunur. Askerî, ruz-1 mahşerde "göz ucuyla" kendisine "gel" diye işaret kılacağını ümit ettiği Hz. Muhammed Mustafâ'yı "Rahmetenli'l-Âlemîn"; "Hak Resûl"; "Hazret-i Hakkun habîbi"; "derdlü cânlara tabîb"; "bahr-1 "ummân-1 sahâvet" gibi sözlerle anlatır.

Askerî, "Yâ 'Aliyye'l-Murtezâ" hitab1 ve "cânımun cânânı"; "gönlümün sultânı" sensin yalvarışıyla sı̆̆ındığı Hz. Ali’yi de "rehber-i râh-1 Hudâ"; mazhar-1 sırr-1 Hudâ"; "nûr-1 pâk-i Mustafâ"; "merci'-i keşf-i kerâmet"; " menba'-1 'ilm-i ledün"; "serverân-1 evliyâ" olarak tavsif eder. Askerî, diğer şiirlerinde olduğu gibi na"tlarında ayet, hadis ve tasavvufi söyleyişlere yer vererek anlatmak istediğine bir derinlik ve inandırıcılık kazandırır.

"Gün yüzün "seb 'a'l -mesâni” kaşlarun Rahmân senün

Her sözün kand-i melâhat Yâ Muhammed Mustafầ" (Sar1, 2016, s. 185)

$* *$

“'Askerîyye kılsun vaslun erzânı

Firâkun âteşi yandırdı cânı

Ey yüzi "âyet-i seb 'a'l-mesânî”

Bize eyle şefâ 'at Yâ Muhammed” (Sarı, 2016, s. 225)

$* *$

"Cümle cihânun cânı bahr-ı tevhîdün kânı

Sirr-ı "seb 'a'l-mesânî" sensin Yâ Resûla'llâh” (Sarı, 2016, s. 404) 
"Seb‘a'l -mesânî": "Ve lekad âteynâke seb‘an mine'l mesânî ve'l Kur’âne'l azîm”: “And olsun ki, biz, sana, (her namazda) okunup tekrarlanan "yedi âyeti" (Fâtiha suresini) ve şu büyük Kur'ânı verdik." Hicir/87.

"Mushaf-ı hüsnünde gördüm âyet-i "ve'ş-şemsi”"yi

Saçı "ve'l-leyli" yüzi hem "ve'd-duhâ"dur "ve'd-duhâ" (Sarı, 2016, s. 186)

**

"Kâkülün "ve'l-leyli"dür nûr-l 'izârun "ve'd-duhâ"

'Âlemi kıldun temâmet şems-i zâtunla ziyâ’” (Sar1, 2016, s. 466)

Şems/1

"Ve'ş-şemsi...": "Ve'ş-şemsi ve'd-duhahe": "And olsun, güneşe ve onun aydınlığına".

"Ve'l-leyli...": "Ve'l-leyli izâ yagşâ”: "Ziyasını örtüp bürüdüğü zaman geceye" Şemş/4

"Ve'd-duhâ": "And olsun kuşluk vaktine" Duhâ/1

"Hamdüli'llâh" çok şükür bî-çâre Dervîş 'Askerî

Âsitân-ı devletinde bir gedâdur bir gedâ" (Sar1, 2016, s. 186)

"El-Hamdüli’llâh....": “El-hamdü li'llâhi Rabbi'l âlemin”: “O Rahman, O Rahîm olan Allâh'ın adıyla" Fâtiha/1

"Hâl-i ruhsârun misâl-i nokta-i "bismi'llâh"da

Strr-ı remz-i "hel etâ"sin Yâ 'Aliyye'l-Murtezâ" (Sar1, 2016, s. 188)

"Hel etâ...": "Hel etâ ale'l-insâni hînun mine'd-dehri lem yekün şey’en mezkûrâ": "Gerçekten insan üzerine dehirden öyle bir zaman geçti ki, o vakit insan anılır,(insanlıkla tanılır) bir şey değildi.” İnsân/1

"Bi'smi'llâhi'r-rahmâni'r-rahîm": "Rahman ve rahim olan Allâh'ın adıyla". Kur'ânKerim'de sûrelerin başında, Hûd suresi 41. âyette ve Neml suresi 30. âyette geçer (Sarı, 2009, s. 631)

"Kâbe kavseyn" kaşlarun sırr-ı "ev ednâ" dur yüzün

“Ve sekâhüm rabbühüm”câmın sunar câna sözün” (Sarı, 2016, s. 471)

"Kâbe kevseyn": "Fe kâne kâbe kavseyn, ev ednâ": "(Böylece peygamberlere olan mesafesi) iki yay arası kadar, yahut daha az oldu." Necm/9

"...Vesakâhum rabbuhum şarâben tahûra...": "...Rableri de onlara tertemiz bir şarap içirmiştir". İnsan/21

"Kenz-i mahfî"nün tılısmın bozup itdün âşikâr

Eyledün 'aşk u mahabbet dürlerin halka nisâr'” (Sarı, 2016, s. 466)

$* *$

“Küntü kenz”ün mazharl Allâhun Peygamberi

‘İlm-i ledün serveri sensin Yâ Resûla'llâh” (Sarı, 2016, s. 405)

$* *$

"Ey cihânun mebde'i ey mefhar-i halk-ı cihân

“Küntü kenz”ün cevheri gencîne-i kenz-i nihân” (Sar1, 2016, s. 463) 


\author{
“Kaти mü'minlerün sen rehberisin \\ "Küntü kenz" gencinün ol cevherisin \\ Cemî'-i enbiyânun serverisin \\ Bize eyle şefâ 'at Yâ Muhammed" (Sar1, 2016, s. 224)
}

"Kenz-i mahfî" (gizli hazine): "Küntü kenzen mahfiyyen": "Allâhü te‘âlâ buyurur: "Ben gizli bir hazine idim, bilinmek istedim ve insanı yarattım." Aclûnî, Keșfü'l Hafâ,2/132. (Daha çok mutasavvıflarca kullanılan söz üzerine hadis bilginleri farklı görüştedirler. (Yılmaz, 1992, s. 91).

"A 'zam-l şânunda "levlâk" diyü Hakdan hem senün

Nâzil oldı nice âyet Yâ Muhammed Mustafầ" (Sar1, 2016, s. 185)

**

“Şânuna "levlâke levlâk” didi Rabbü’l- 'âlemîn

Pâyuna yüz sürdi Mi 'râc gicesi ‘arş-ı berîn” (Sarı, 2016, s. 464)

"Levlâke levlâk lemâ halaktü'l eflâk": "(Ey Muhammed) sen olmasaydın, felekleri (âlemleri) yaratmazdım." Hadis-i Kutsi, sahih değildir. (Y1lmaz, 1992, s. 113).

“Rahmetenli'l-âlemîn”sin Hak Resûlsün bî-gümân

İderem ben de şehâdet Yâ Muhammed Mustafâ" (Sarı, 2016, s.185)

"Erselnâke illâ rahmetenli'l-âlemîn": "Seni de (ey Resûlüm), ancak âlemlere rahmet olarak gönderdik" Enbiya/107.

"Rahmetenli'l-'âlemîn": Hz. Peygamber Efendimiz için söylenmiş bir lâkap olup dinî ve tasavvufî şiirlerde çokça geçer. "Âlemlere rahmet olarak (gönderdik)" manasındadır (Yılmaz, 1992, s. 137).

\title{
7. "Na't'larm Metinleri
}

\section{I}

\section{Fâ‘ilâtün Fâ'ilâtün Fâ‘ilâtün Fâ'ilün}

Ben za'îfe k1l şefâ'at Yâ Muhammed Mustafầ

Sensin ol nûr-1 hidâyet Yâ Muhammed Mustafâ

Ağlayu kapuna geldüm sen beni reddeyleme

İsterem senden 'inâyet Yâ Muhammed Mustafâ

Yarın ol mahşer yerinde suçumı Hak'dan dile

Kılmasın halka melâmet Yâ Muhammed Mustafâ

Çok günâhun ıssıyam şâhum bana hışm eyleme

Lutf idüp itme hakâret Yâ Muhammed Mustafâ

\footnotetext{
${ }^{2}$ A: 3a; B:59a; C:34a; D: 3a; E:74b; F: 2b; H: 3a
} 
Da'vet it 'aşkun livâsı altına ey pür-'atâ

Olıcak rûz-1 kıyâmet Yâ Muhammed Mustafâ

"Nefsî nefsî̀" didügi dem anda cümle enbiyâ

Sen bize eyle 'inâyet Yâ Muhammed Mustafâ

Kim ola şer'-i sırât-1 müstakîm üzre sana

İde bile istikâmet Yâ Muhammed Mustafâ

Sensin ol mir'ât-1 hazret berzeh-i kübrâ-yı Hak

Kim bula sana nihâyet Yâ Muhammed Mustafâ

Kimse bilmez vahdetüni nicedür ol Hakkile

Yok senün künhüne gâyet Yâ Muhammed Mustafầ

Şol hakîkat ümmet olan kişilerün cânına

Zî-beşâret zî-sa'âdet Yâ Muhammed Mustafâ

N'ola bir kez göz ucuyla derd-mend bî-çâreye

Gel diyü k1lsan işâret Yâ Muhammed Mustafâ

Nâr-1 firkatle yakarsun dâ'imâ dil-hasteyi

Bu mıdur 'uşşâka 'âdet Yâ Muhammed Mustafâ

Mâh-1 vechün görmegi dâ'im temennâ iderem

K1l temennâmı icâbet Yâ Muhammed Mustafâ

Şerbet-i vaslun irişdür yohsa oldum ben helâk

Kalmadı hîç sabra tâkat Yâ Muhammed Mustafâ

Vuslatun peymânesinün nûş iden bir cür'asın

Dü-cihânda oldu râhat Yâ Muhammed Mustafâ

İçmeyen âb-1 zülâlün çeşmesinden tâ ebed

Bulmadı bulmaz selâmet Yâ Muhammed Mustafâ 
Virmeyen cânın visâlün '1ydına kurbân içün

Gitmedi andan kerâhet Yâ Muhammed Mustafâ

Gün yüzün "seb'a’1 -mesâni” kaşlarun Rahmân senün

Her sözün kand-i melâhat Yâ Muhammed Mustafâ

A ‘zam-1 şânunda "levlâk" diyü Hakdan hem senün

Nâzil oldı nice âyet Yâ Muhammed Mustafâ

“Rahmetenli’l-Âlemîn"sin Hak Resûlsün bî-gümân

İderem ben de şehâdet Yâ Muhammed Mustafâ

Hazret-i Hakkun habîbi derdlü cânlara tabîb

Bahr-1 'ummân-1 sahâvet Yâ Muhammed Mustafâ

Bin y1l ‘ömrüm olsa şerh itsem kemâlün vasfinı

Bulmayam hergiz kanâ‘at Yâ Muhammed Mustafâ

Düşeli sevdâ-y1 'aşkunla hayâlün fikrine

Bilmez oldum 'arz-1 tâ'at Yâ Muhammed Mustafâ

'Askerî gönlünde ancak şevk-i zâtundur hemân

Kalmadı bir gayri hâcet Yâ Muhammed Mustafầ (Sarı, 2016, s. 183-185)

II

\section{Fâ'ilâtün Fâ'ilâtün Fâ'ilâtün Fâ'ilün}

Cân içinde bulduğum şol Mustafâdur Mustafâ ${ }^{3}$

Cân u dilden sevdiğim ol meh-likâdur meh-likâ

Togdı çün cân meşrıkından şems-i nûr-i tal'ati

Hamdüli’llâh hâne-i dil pür-ziyâdur pür-ziyâ

Görinür Hakkun cemâli hûb cemâlinde anun

Oldurur mir’ât-1 hazret Hak-nümâdur Hak-nümâ

\footnotetext{
${ }^{3}$ A: 4a; C:46a; D: 4a; E:75b; F: 2b; H: 4a
} 
Mushaf-1 hüsnünde gördüm âyet-i "ve'ş-şemsi”yi

Saçı “ve'l-leyli” yüzi hem "ve'd-duhâ"dur "ve'd-duhâ"

Sa'y idüp irdim hakîkat şehrinün bayrâmına

'Iyd-1 ekberdür bugün gel merhabâdur merhabâ

İrişüp bezm-i visâle câm-1 la'linden anun

Nûş-1 câm itmek zülâlin hoş safâdur hoş safâ

Râh-1 'aşkında yüzüm sürsem revâdur yerlere

Hâk-i pâyı gözlerime tûtiyâdur tûtiyâ

‘Âşık-1 sâdıklarına çok 'atâlar kı1ıcı

Lutfunun pâyânı yok bir bü'l-vefâdur bü'l-vefâ

"Hamdüli’llâh” çok şükür bî-çâre Dervîş 'Askerî

Âsitân-1 devletinde bir gedâdur bir gedâ (Sarı, 2016, s. 183-186)

III

\section{Fâ'ilâtün Fâ'ilâtün Fâ'ilâtün Fâ'ilün}

Rehber-i râh-1 Hudâsın Yâ 'Aliyye'l-Murtezâ ${ }^{4}$

Mazhar-1 sırr-1 Hudâsın Yâ 'Aliyye'l-Murtezâ

"Nûrun alâ-nûr" didi şânunda fahr-i kâ'inât

Nûr-1 pâk-i Mustafâsın Yâ 'Aliyye'l-Murtezâ

Şol kerem-kânı mürüvvet ma'deni sâhib-'atâ

Mahzen-i genc-i 'atâsın Yâ 'Aliyye'l-Murtezâ

Merci'-i keşf-i kerâmet menba'-1 'ilm-i ledün

Serverân-1 evliyâsın Yâ 'Aliyye'l-Murtezâ

Şîr-i yezdân merd-i merdân fâris-i meydân-1 Hâkk

Dîn yolunda cân fedâsın Yâ 'Aliyye'l-Murtezâ

\footnotetext{
${ }^{4}$ A: 4b; B:35a; C:15a ve 45b; D: 4b; E:41b; F: 3b; H: 4b
} 
Çünki On İki İmâmun aslısın ey pâk-i zât

Mesned-i ‘âl-i ‘abâsın Yâ 'Aliyye'l-Murtezâ

Şehr-i 'ilmün bâbısın 'ummân-1 'aşkun cevheri

Kenz-i ‘irfân-1 hafâsın Yâ 'Aliyye'l-Murtezâ

Görinür mir'ât-1 hüsnünde cemâl-i nûr-1 zât

Hâk budur kim Hak-nümâsın Yâ 'Aliyye'l-Murtezâ

Zât-1 vahdetden haber verir sıfâtun ser-te-ser

Şübhesüz ‘ayn-i likâsın Yâ ‘Aliyye’l-Murtezâ

Hâl-i ruhsârun misâl-i nokta-i bismi'llâhda

Sirr-1 remz-i "hel etâ"sın Yâ 'Aliyye'l-Murtezâ

Âsitân-1 devletündür Kâ‘besi ‘âşıklarun

Merve vü ‘Umre Safâsın Yâ ‘Aliyye’l-Murtezâ

İrse fazlun âbına bulur şifâyı bir 'alîl

Hasta cânlara devâsın Yâ 'Aliyye'l-Murtezâ

'Askerî dir nice sayd itsün seni tab'-1 mekes

Murg-1 lâhût-1 hümâsın Yâ 'Aliyye’l-Murtezâ(Sar1, 2016, s. 187-188)

IV

\section{Fâ'ilâtün Fâ'ilâtün Fâ'ilâtün Fâ'ilün}

Cânımun cânânı sensün Yâ 'Aliyye'l-Murtezâ ${ }^{5}$

Gönlümün sultânı sensün Yâ 'Aliyye'l-Murtezâ

Varlıgım ‘ömrüm hayâtım sıhhatimsin bî-gümân

Cismimün hem cânı sensün Yâ ‘Aliyye'l-Murtezâ

On sekiz bin 'âlemün sırrında seyrân eyleyen

Rûh-1 reyhânı çü sensün Yâ 'Aliyye'l-Murtezâ

\footnotetext{
${ }^{5}$ A: 5a; B:13b; D: 4b; E:16b; F: 4a; H: 5a; I: 1b
} 
Vechüne kıldım nazar çün haste-dil buldı şifâ

Derdimün dermânı sensün Yâ ‘Aliyye’l-Murtezâ

Görinür mir’ât-i hüsnünde cemâl-i lem-yezel

Sûret-i Rahmânî sensün Yâ 'Aliyye'l-Murtezâ

"Vâhidün min nûri"didi şânunda şâh-1 enbiyâ

Mazhar-1 subhânî sensün Yâ 'Aliyye'l-Murtezâ

Menba'-1 'ilm-i ledünnî mahzen-i esrâr-1 Hak

'İlm-i ‘irfân kânı sensün Yâ 'Aliyye’l-Murtezâ

Zâhir ü bâtında râh-1 vahdet-i zâtiyyeye

‘Âşıkun bürhânı sensün Yâ 'Aliyye'l-Murtezâ

Kâfir ü münkir münâfikdur seni inkâr iden

Mü’minün îmânı sensün Yâ 'Aliyye'l-Murtezâ

Sırrını esrâr-1 Hakka irgüren ‘âriflerün

Sırrınun seyrânı sensün Yâ 'Aliyye'l-Murtezâ

Sirr-1 zâtundan okur esrâr-1 vahdet 'ilmini

‘Ârifün dîvânı sensün Yâ 'Aliyye'l-Murtezâ

Bû-y1 gül-zâr-1 cemâlün cânumı mest eyledi

Gönlümün reyhânı sensün Yâ 'Aliyye'l-Murtezâ

Hamdüli’llâh 'Askerî olmaz cemâlünden cüdâ

Kalbinün mihmânı sensün Yâ 'Aliyye'l-Murtezâ (Sarı, 2016, s. 188-189)

V

\section{Mefâ‘îllün Mefâ‘îlün Fe'ûlün}

1

Elâ ey ma'den-i kân-1 risâlet ${ }^{6}$

Bize eyle şefâ‘'at Yâ Muhammed

${ }^{6} \mathrm{~A}: 14 \mathrm{a} ; \mathrm{C}: 21 \mathrm{~b} ; \mathrm{D}: 13 \mathrm{a} ; \mathrm{F}: 10 \mathrm{a} ; \mathrm{H}: 14 \mathrm{~b}$ 
Veyâ ey mazhar-1 nûr-1 hidâyet

Bize eyle şefâ'at Yâ Muhammed

2

Kamu mü’minlerün sen rehberisin

“Küntü kenz" gencinün ol cevherisin

Cemî‘-i enbiyânun serverisin

Bize eyle şefâ'at Yâ Muhammed

3

Yer ü gök 'arş u kürsî levh ü kalem

Melek şeytân ü cinn ü dîv ü âdem

Seninçün yaradıldı cümle 'âlem

Bize eyle şefâ‘ at Yâ Muhammed

4

Sifâtu'llâh-1 zâtsın zâta mir'at

Cemâlünde görinür hazret-i zât

Hakîkat hakkı kılan sensin isbât

Bize eyle şefâ'at Yâ Muhammed

5

İdüp kenz-i mahabbet feth-i bâbın

Görem hüsnün ilinün âfitâbın

İçür lâ‘lün zülâlinün şarâbın

Bize eyle şefâ‘ at Yâ Muhammed

6

Gözüm gözler gice gündüz hayâlün

Umar cânum görem deyü cemâlün

Temevvüc eyleyüp bahr-1 kemâlün

Bize eyle şefâ'at Yâ Muhammed

7

Mukbil ü mahrem ü hâs u haremsin

Tâvus-1 lâhût-1 bâg-1 İremsin

'Atâlar kılıcı sâhib-keremsin

Bize eyle şefâ'at Yâ Muhammed

8

Şerî‘at emrine boyun virelüm

Tarîkat yoluna togrı varalum

Visâlün Kâ‘besin varup görelüm 
Bize eyle şefâ'at Yâ Muhammed

9

'Askerîyye k1lsun vaslun erzânı

Firâkun âteşi yandırdı cânı

Ey yüzi âyet-i seb'a’l -mesânî

Bize eyle şefâ'at Yâ Muhammed (Sarı, 2016, s. 224-225)

\section{VI}

\section{Mefâ‘îlün Mefâ‘îlün Fe‘ûllün}

1

Günâhkâr ümmete idüp şefâ' at ${ }^{7}$

Meded eyle meded Yâ Resûla'llâh

Çü sensün menba'-1 kân-1 hidâyet

Meded eyle meded Yâ Resûla'llâh

2

Şefâ'at şerbetine bizi kandur

Mahabbet refrefine cânı bindür

Cemâlün şem'asını dilde yandur

Meded eyle meded Yâ Resûla'llâh 3

İrişdür bizi dergâh-1 a‘lâya

İrişelüm varup asıl sılaya

Belâdan kurtarup irgür velâya

Meded eyle meded Yâ Resûla'llâh

4

Seni Hak cümleden esbak yaratd 1

Vücûdun mahzen-i hikmet yaratdı

Dü-'âlemde seni Rahmân yaratdı

Meded eyle meded Yâ Resûla'llâh

5

Vücûdun mazhar idüp künh-i zâta

Sebeb k1ldı cemî'-i kâ'inâta

Nazar kılup kamu ehl-i 'usâta

Meded eyle meded Yâ Resûla'llâh

6

${ }^{7}$ A:69a; B:29a; C: 11a; D:60a; E:34a; F:48a; G:67a; H:66a; I:2b 
Vesîle Cennetini feth-i bâb it

Cemâlünden bize ref'-i hicâb it

Tecellî-i cemâl-i âfitâb it

Meded eyle meded Yâ Resûla'llâh

7

İrişdür Cennete hâs ile ‘âmın

Bula ebrâr mukarreb hep makâmın

Sunup 'uşşâka vaslun bezm-i câmın

Meded eyle meded Yâ Resûla'llâh

8

Ne var biz eyledükse sehv ü 'isyân

Keremler kânısın sen eyle ihsân

Umar senden şefâ'at cinn ü insân

Meded eyle meded Yâ Resûla'llâh

9

Sözündür 'ârifün dilde beyânı

Yüzündür sûre-i "seb'a'l-mesânî”

Özündür 'Askerînün cânda cânı

Meded eyle meded Yâ Resûla'llâh (Sarı, 2016, s. 407-408)

\section{VII}

\section{Fâ‘ilâtün Fâ‘ilâtün Fâ‘ilâtün Fâ'ilün}

\section{1}

Bülbül-i bâg-1 ledünnî tûti-i şî̂ñn-edâ ${ }^{8}$

Ey gül-i gül-zâr-1 ma'nâ pertev-i nûr-1 Hudâ

Garka-i envâr-1 lâhût bahrî-i bahr-1 fenâ

Hem-dem-i bezm-i hakîkat vâsıl-1 'ayn-1 likâ

Çok selâm olsun sana ey yâr-1 sâdık Mustafâ

Mahzen-i genc-i vefâsın ma'den-i sıdk u safâ

2

Kıble-i ervâhiyâna Mekketu'llâhdur yüzün

Secde-i kerrûbiyâna beyt-i ma 'mûrdur özün

"Kâbe kavseyn" kaşlarun sırr-1 "ev ednâ"dur yüzün

"Ve sekâhüm rabbühüm”câmın sunar câna sözün

Çok selâm olsun sana ey yâr-1 sâdık Mustafâ

\footnotetext{
${ }^{8}$ A:86a; D:75b; G:85a; H:84a
} 
Mahzen-i genc-i vefâsın ma‘den-i sıdk u safâ

3

Zâtile kılmış tecellî sırruna esrâr-1 Hû

Çağırup söyler ene'l-Hak cümle 'uzvun mû-be-mû

Gösterüp Hakkun sıfâtun şerh ider a'zân kamu

"Ahsen-i takvîm" dinildi şânuna ey Hak-nümû

Çok selâm olsun sana ey yâr-1 sâdık Mustafâ

Mahzen-i genc-i vefâsın ma'den-i sıdk u safâ

4

Küllî eşyâ sana tâlib cümlenün sen zâtısın

Âfitâb-1 tâb-1 'âlem nûrınun zerrâtısın

Mazhar-1 'ilm-i Hudâsın zâtınun sıfâtısın

Seyr ider sende cemâlin sen Hakun mir'âtısın

Çok selâm olsun sana ey yâr-1 sâdık Mustafâ

Mahzen-i genc-i vefâsın ma'den-i sıdk u safâ

5

'Âlem-i kesretde buldun 'ayn-1 vahdet sırrını

"Semme vechu'llâh" imiş bildün bu kesret sırını

Okıdun levh-i gönülde 'ilm-i hikmet sırrını

Bildürübdür Hak sana izhâr-1 kudret sırrını

Çok selâm olsun sana ey yâr-1 sâdık Mustafâ

Mahzen-i genc-i vefâsın ma'den-i sıdk u safâ

6

Mürşid-i kâmilden aldun sen ledünnî dersüni

Hulle-i ma'nâ biçersin buldun ol firdevsüni

“Men 'aref” esrârına vâkıf idelden nefsüni

Şast idüp urdun şikârun ele alup kavsüni

Çok selâm olsun sana ey yâr-1 sâdık Mustafâ

Mahzen-i genc-i vefâsın ma'den-i sıdk u safâ

7

Dil visâlün Kâ‘besinün gencine irmek diler

Vaslınun '1ydına kurbân cânını virmek diler

Şol cemâlün gülşeninün güllerin dirmek diler

Sohbetünde bezm-i hüsnün zevkini sürmek diler

Çok selâm olsun sana ey yâr-1 sâdık Mustafâ

Mahzen-i genc-i vefâsın ma‘den-i sıdk u safâ 
8

Yâd idüp zikrün du'â-i hayrile ey dost müdâm

El açup idüp temennâ budurur Hakdan ricâm

Saklayup cümle belâlardan vücûdunı Hudâm

'Ömrüni kılsun hemîşe devletiyle müstedâm

Çok selâm olsun sana ey yâr-1 sâdık Mustafâ

Mahzen-i genc-i vefâsın ma'den-i sıdk u safâ

9

Buldun âdem sırrını oldun kerâmet mazharı

Sendedür ol câm-1 Cem âyîne-i İskenderî

On sekiz bin 'âlemi seyr itdi sende 'Askerî

Ey tarîk-i halvetîde ehl-i diller serveri

Çok selâm olsun sana ey yâr-1 sâdık Mustafầ

Mahzen-i genc-i vefâsın ma‘den-i sıdk u safâ (Sarı, 2016, s. 470-472)

\section{VIII}

\section{Fâ‘ilâtün Fâ'ilâtün Fâ'ilâtün Fâ'ilün}

1

Ey cihânun mebde'i ey mefhar-i halk-1 cihân ${ }^{9}$

“Küntü kenz”ün cevheri gencîne-i kenz-i nihân

Gülşen-i verd-i hakîkat şâh-1 taht-1 lâ-mekân

Mecma'-i esrâr-1 vahdet gevher-i 'irfâna kân

Nûr-1 zâtunla müzeyyendür senün kevn ü mekân

Hûb-cemâlünle münevver ravza-i bâg-1 Cinân

Şol cemâlün şemsine bir zerredür her mihribân

Ol kemâlün bahrına bir katredür âb-1 revân

Sen vücûda gelmesen olmazdı 'âlem bî-gümân

Öz vücûdundur cemî‘-i ‘âlemün cânına cân

Her nihân oldı 'ademden nûr-1 vechünle 'yyân

Zâhir oluben sıfatlar virdi varlıkdan nişân

Küllî eşyâ hep delâ'il vasfunı eyler beyân

Berr ü bahr ü 'arş ü kürsi levh ü kalem âsmân

Sensin ol mahbûb-1 Hak Peygamber-i âhir-zamân

Senden oldı âşikâre sırr-1 emr-i "kün fekân"

Ben günah-kâr ‘âsî vü mücrim za‘îf ü nâ-tüvân

\footnotetext{
${ }^{9}$ A:83b; B:43a; C:26a; D:73b; E:53b; G:83a; H:82a
} 
Derd-i 'aşkunla dem-â-dem eyleyüp âh ü figân

Rûz u şeb senden Habîbâ dilegüm budur hemân

Kıl şefâ'at el-amân ey kân-1 rahmet el-amân

2

Şânuna “levlâke levlâk” didi Rabbü'l- 'âlemîn

Pâyuna yüz sürdi Mi'râc gicesi 'arş-1 berîn

Emrüne fermân olur her demde Cebrâîl Emîn

Ümmetün olmagı devlet bildiler hep mürselîn

Takd1 kudret destüne hatm-i nübüvvet hâtemîn

Nâzil oldı âyet âyet sana Kur'ân-1 mübîn

Mahzen-i 'aşkundan aldılar kemâli kümmelîn

Tolıdur esrâr-1 vahyünle kulûb-1 ekmelîn

Sen hakâyık şehrinün sultânısun Hakka'l-yakîn

Senden âhir kimseden ummaz vefâ ashâb-1 dîn

On sekiz bin âlem içre sensin ol şâh-1 güzîn

'Âm u hâsun hep ümîdi cûd-1 fazlundur hemîn

Gerçi azdırdı bizi yolunda İblîs-i la'în

Lîk sensin Yâ Resûla'llâh şefi'ü'l-müznibîn

Sen eger olmaz isen ben derd-mendüne mu'în

Hâlüme aglaşalar yarın melâ'ik ecma‘în

Rûz-1 mahşerde 'usâta oldugun içün zamîn

Yüz tutup dergâhuna dâ'im bu miskîn kemterin

Rûz u şeb senden Habîbâ dilegüm budur hemân

K1l şefâ‘at el-amân ey kân-1 rahmet el-amân

3

Künh-i zâtun mazharıdur dâne-i kenz-i hafâ

Kâ'inâtun rehberi ey merd-i meydân-1 Hudâ

Sâkî-i bezm-i elest deryâ-y1 'irfần-1 rıza

Bülbül-i kuds-i gülistân bâg-1 reyhân-1 'amâ

Zübde-i mahlûk-1 'âlem şâh-1 hatm-i enbiyâ

Nefha-i ervâh-1 âdem nûr-1 pâk-i Hak-nümâ

Menba'-1 esrâr-1 hikmet ma'den-i sıdk u safâ

Nûr-1 Yezdân Ahmed ü Mahmûd Muhammed Mustafâ

Kâkülün "ve'l-leyli”dür nûr-1 'izârun "ve'd-duhâ"

'Âlemi kıldun temâmet şems-i zâtunla ziyâ

Âfitâb-1 tal'atınun zerresidür enbiyâ 
Âsitân-1 şer'inün hep bendesidür evliyâ

Ey mürüvvet sâhibi lutfunla fazlun kıl revâ

Hasta cânlara yetişsün âb-1 fazlundan devâ

Ni‘met-i 'aşkunla toyla oldurur câna gıdâ

Râh-1 'aşkunda nice bin cân ü baş olsun fedâ

Çün cenâbundur muhakkak mürşid-i râh-1 Hudâ

El açup idüp temennâ hazretünden ben gedâ

Rûz u şeb senden Habîbâ dilegüm budur hemân

Kil şefâ'at el-emân ey kân-1 rahmet el-emân

4

“Kenz-i mahfî”nün tılısmın bozup itdün âşikâr

Eyledün 'aşk u mahabbet dürlerin halka nisâr

Seni mir'ât eyledi öz zâtuna perverd-gâr

Görinür mir'ât-1 vechünde cemâl-i -Kird-gâr

Yer ü gök ü 'arş u kürsî ins ü cinn ü mûr u mâr

Küllî mevcûdât senünle eyler ey mâh iftihâr

Zülfinün bendine bend olup nice bin şehr-yâr

Raht ü bahtın tâc ü tahtın eylediler târ-mâr

Zâhidün kalbinde Cennet hubbı itdiyse karâr

'Âşıkun cânda çerâgı şem'-i hüsnünden yanar

'Aşkunı sayd itmege her kişide yok iktidâr

Nice itsün bir mekes simurg (u) 'ankâyı şikâr

Zülf-i 'anber-bûyuna öykünemez Müşk-i Tatar

Hüsn-i ruhsârun katında gül hacîl ü şerm-sâr

Vasluna irmek içün Mecnûn-sıfat leyl ü nehâr

Hayretün sahrâsını dil bekler oldı intizâr

Ben garîb ü bî-kes ü bî-çâre mânend-i hezâr

Derdile her-dem idüp feryâd ü nâlânile zâr

Rûz u şeb senden Habîbâ dilegüm budur hemân

K1l șefâ'at el-emân ey kân-1 rahmet el-emân

5

Sirr-1 zâtuna tecellî eyleyüp künh-i celâl

On sekiz bin 'âlem içre toldı envâr-1 cemâl

Sûret-i nakşuna düşmüşdür dü-‘âlem bir hayâl

Sîretün fehmine irmek 'akl-1 küllîye muhâl

Bahr-1 bî-pâyân sıfâtundur senün bî-kîl u kâl 
Kim ola deryâ-yı zâtun vasfina ide makâl

Bir kemâl-i mâh-tâbsın bedrün olmaz hîç hilâl

Bir cemâl-i âftâbsın hüsnüne yokdur zevâl

Nice medh idem kemâlün ben senün ey pür-kemâl

Nice bin şîrîn-zebân medhünde 'âciz oldı lâl

Oldılar şunlar cihânda şöyle kim ehl-i dalâl

İtmediler zâhir ü bâtında sana imtisâl

Yoluna terk itmeyince cân ü baş ü mülk ü mâl

İrmedi kimse sarây-1 vasluna bulup visâl

Yanmışam derdün odına yâ Habîb-i lâ-yezâl

Çeşme-i lâ‘ l-i lebünden sun bana âb-1 zülâl

N'eylesün bu 'Askerî kim bir za 'îf ü bî-mecâl

Sehv ü 'isyânile 'ömri geçdi bunca mâh u sâl

Rûz u şeb senden Habîbâ dilegüm budur hemân

K11 şefâ‘at el-emân ey kân-1 rahmet el emân (Sarı, 2016, s. 463-468)

\section{IX}

Hece: 14 (7+7)

'Ömrimün sermâyesi sensin Yâ Resûla'llâh ${ }^{10}$

Kudretu'llâh mâyesi sensin Yâ Resûla'llâh

Hüviyy hüviyyet fezâ 'irfân-1 Hak u rızâ

Zikr-i ‘adle muktezâ sensin Yâ Resûla’llâh

Hem ezelsin hem ebed vâhid ü ferd ü ehad

Sirr-1 sıfât-1 samed sensin Yâ Resûla'llâh

Yogiken kevn ü mekân var olmadan 'akl ü cân

Küllî gevherlere kân sensin Yâ Resûla'llâh

Esrâr-1 genc-i nihân sende oldı çün '1yân

Cümleden maksûd hemân sensin Yâ Resûla'llâh

Kenz-i mahfîye miftâh eyledi seni fettâh

Ümmü'l-hulk ebü'l-ervâh sensin Yâ Resûla'llâh

${ }^{10}$ A:67b; B:3a; D:59a; E:4a; F:47a; G:66a; H:65a 
Olmasaydun sen mevcûd bulmazdı 'âlem vücûd

Envâr-1 deryâ-yı cûd sensin Yâ Resûla'llâh

'Aşkundur rûha gıda yoluna cânlar fedâ

Makbûl-1 Bâri Hudâ sensin Yâ Resûla'llâh

Ma'den-i 'ilm ü kerem bülbül-i bâg-1 İrem

Mahrem-i hâss-1 harem sensin Yâ Resûla'llâh

Mevc urup 'aşkun bahri akdı mahabbet nehri

İki cihânun fahri sensin Yâ Resûla’llâh

'Askerî miskin fakîr derdünle olmış esîr

Düşmüşlere dest-gîr sensin Yâ Resûla'llâh (Sarı, 2016, s. 402-403)

\section{$\mathbf{X}$}

Hece: $14(7+7)$

Gönlimün eglencesi sensin Yâ Resûla'llâh ${ }^{11}$

Bâg-1 vahdet goncesi sensin Yâ Resûla'llâh

Râgıblarun mergûbı tâliblerün matlûbı

'Âşıklarun mahbûbı sensin Yâ Resûla'llâh

‘Âriflerün ‘irfânı evliyânun bürhânı

Enbiyânun sultânı sensin Yâ Resûla'llâh

Ol matla'-1 nûr-1 zât menba'-1 âb-1 hayât

Merci‘-i külli-sıfât sensin Yâ Resûla’llâh

Şems-i cemâlünden tâb alur dâ'im âfitâb

Nüsha-i ümmü'l-kitâb sensin Yâ Resûla'llâh

Yüzün "sûre-i Rahmân" saçun sübha-i sübhân

"Tâhâ" "Yâsin” ü "Fürkân” sensin Yâ Resûla'llâh

\footnotetext{
${ }^{11}$ A:68a; B:5a; D:59a; E:7a; F:47b; G:66b; H:65b
} 
Cümle cihânun cânı bahr-1 tevhîdün kânı

Sirr-1 “seb'a’l -mesânî” sensin Yâ Resûla'llâh

Murg-1 lâhût-1 hümâ gülşen-i verd-i 'amâ

Zât-1 pâk-1 Hak-nümâ sensin Yâ Resûla'llâh

Nefha-i ibn-i Meryem Kâ‘be-i âb-1 zemzem

Gönül derdine merhem sensin Yâ Resûla'llâh

'Aşkuna düşen 'âş1k olmaz dün ü gün ayık

Hakîkatü'l-hakâyık sensin Yâ Resûla'llâh

Başumda tâc ü külâh 'aşkundur ey Pâdişâh

Mahzen-i genc-i İlâh sensin Yâ Resûla'llâh

'Askerî kemter kemîn umar vaslun merhemin

“Rahmeten li’l-âlemîn” sensin Yâ Resûla'llâh (Sarı, 2016, s. 403-404)

\section{XI}

\section{Hece: $14(7+7)$}

Lâmi'-i envâr-1 zât sensin Yâ Resûla'llâh ${ }^{12}$

Câmi`-i küllî sıfât sensin Yâ Resûla’llâh

Deryâ-y1 'ilm-i hikmet 'ankâ-y1 kâf-1 kudret

Sâki-i bezm-i vahdet sensin Yâ Resûla'llâh

Lebün çeşme-i hayvân yüzün sûre-i Rahmân

Cümle derdlere dermân sensin Yâ Resûla'llâh

Ey yüzi gül alnı ay lutfun umar yohsul bây

Mahrem-i vahdet-sarây sensin Yâ Resûla'llâh

Tevhîd-i zât-1 'irfân cânlar içinde cânân

İki cihânda sultân sensin Yâ Resûla'llâh

${ }^{12}$ A:68b; D:59b; F:48a; G:66b; H:65b 
Tâliblerün bürhânı 'âriflerün seyrânı

Hakkun bize ihsânı sensin Yâ Resûla'llâh

“Küntü kenz”ün mazharı Allâhun Peygamberi

'İlm-i ledün serveri sensin Yâ Resûla’llâh

Dil mülkinün bünyâdı mevcûdâtun ma'âdı

Envâr-1 sırr-1 hâdi sensin Yâ Resûla'llâh

'Askerîdür şeydâsı başındadur sevdâsı

Mecnûn dilün Leylâsı sensin Yâ Resûla'llâh (Sarı, 2016, s. 405)

\section{XII}

\section{Hece: $14(7+7)$}

Şefâ'at şem'in yandur meded Yâ Resûla'llâh ${ }^{13}$

Vaslun meyine kandur meded Yâ Resûla'llâh

Yüregüm tolu yâre bulmadım derde çâre

Oldum gâyet bî-çâre meded Yâ Resûla'llâh

Ey menba'-1 hidâyet nûr-1 şems-i sa'âdet

Lutfile kıl inâyet meded Yâ Resûla'llâh

Sana ma'lûm ahvâlüm derdünden za'îf hâlüm

Gayrı yokdur mecâlüm meded Yâ Resûla'llâh

Açıver fazlun bâbın içür 'aşkun şarâbın

Yap bu gönlüm harâbın meded Yâ Resûla'llâh

Bulmak ister bu gönül kurb-1 zâtuna vüsûl

Lutf idüp eyle kabûl meded Yâ Resûla'llâh

Küllî cüz'î hep peydâ senden oldı hüveydâ

Başumdan aşdı sevdâ meded Yâ Resûla'llâh

\footnotetext{
${ }^{13}$ A:69a; D:60a; F:48a; G:67a; H:66a
} 
Dü-‘âlemde hâcetüm 'aşkundadur râhatum

Kalmadı hiç tâkatum meded Yâ Resûla'llâh

'Askerî eydür Yâ Hû işüm hatâdur kamu

Yüzüm karasını yu meded Yâ Resûla'llâh (Sarı, 2016, s. 406)

\section{Sonuç}

$\mathrm{Bu}$ çalışmada, doğumunun 400.yılı anısına Muhammed Askerî’nin hayatı ve divanı üzerinde durularak, başka çalışmalara kaynak olacak şekilde "na'tları"nın metinleri verilmiştir. Hayatı ve "na "tları" üzerinde durulan Halvetî şeyhi Gülaboğlu Muhammed Askerî, divan sahibi mutasavvıf bir şairdir. Aruz ve hece vezniyle yazdığ 4000 beyit civarında manzumeden oluşan divanında değişik türlerde yazılmış şiirler bulunmaktadır. Bağlı bulunduğu tarikatın ilkeleri başta olmak üzere çoğu tasavvufi içerikli bu manzumelerden, Peygamber Efendimiz için yazılan "na 't"ların ayrı bir yeri vardır. Onun edebi şahsiyetinin anlaşılmasında dikkate alınması gereken "na "tlar" dil, üslup, duyuş ve söyleyiş itibariyle dikkat çekicidir. Çalışmada, sağlam kurulmuş metinleri verilen ve her biri "na ' $t$ " türüne gösterilecek güzel örnek durumundaki bu eserlerde Askerî Muhammed'in içten gelen samimi yakarışı görülür:

"N'ola bir kez göz ucuyla derd-mend bî-çâreye

Gel diyü kllsan işâret Yâ Muhammed Mustafâ"

\section{Kaynakça}

Askerî, Dîvân-ı Askerî, 06 Ankara Milli Kütüphane Yz. Nu.:F.B.248. (A); 06 Ankara Milli Kütüphane Yz. Nu.:A.1896. (B); 06 Ankara Milli Kütüphane Yz. Nu.:F.B.285. (C); Konya Mevlânâ Müzesi İhtisas Kütüphanesi Yz. Nu.: 2400. (D); Süleymaniye Kütüphanesi Hac1 Mahmut Efendi Böl (Yahya Ef. Kısmı). Nu.:3374 (E); Süleymaniye Kütüphanesi Haşim Paşa Böl. Nu.:94/1 (F); İstanbul Üniversitesi Kütüphanesi Türkçe Yazma Eserler Yz. Nu.:137/3 (G); İstanbul Üniversitesi Kütüphanesi Türkçe Yazma Eserler Yz. Nu.:2806. (H); 06 Ankara Milli Kütüphane Yz. F.B.627/1 (I).

Aygen, M. S. (1979). Şâir ve Mutasavvıf Gülâboğlu Muhammed Askerî (Hayatı ve Şiirleri), Afyon: Türkeli Matbaasi.

Bakı, E. Â. (1941-1942). "Gülaboğlu Muhammed askerî-hayat ve eserleri”, Taşpınar Dergisi, $86,21-25 ; 87,44-52$.

Canım, R. (2014). Divan edebiyatında Türler, Ankara: Grafiker Yayınları.

Erdoğan, K. (1998). Niyââî-i Mısrî (Hayatı, Edebî Kişiliği, Eserleri) ve Dîvânı (Tenkitli Metin), Ankara: Akçă̆ Yayınları.

Ergun, S. N. (1936). Türk şâirleri, 2, İstanbul.

Gölpınarlı, A. (1971). Mevlânâ müzesi yazmalar kataloğu, 2, Ankara.

Gönçer, S. (1991). Afyon ili tarihi, 2, Afyon.

Güner, H. (1967). Kütahyalı divân şâirleri, halk şâirleri, tekke şâirleri, âşsł ve ozanlar, Kütahya: Kütahya İl Basımevi.

İsen, M. (2011). “Türler”, Eski türk edebiyatı el kitabı (ss. 251-271), Ankara: Grafiker Yayınlar1. 
Sarı, M. (2000). “Gülaboğlu Muhammed askerî dîvânı'nda gönül”, Kütahyalı Şâirler Sетровуити I, 145-177.

Sarı, M. (2007). Askerî Muhammed- hayatı, eserleri, edebî kişiliği-ve divanının tenkitli metni, Afyonkarahisar: AKÜ Yayınları; Yeni baskı: (2016). Afyonkarahisar: Afyonkarahisar Belediyesi Kültür Yayınları.

Sarı, M. (2009). “Askerî Muhammed-Gülaboğlu dîvânı'nda geçen âyetler”, Atatürk Ü. Türkiyat Araştırmaları Enstitüsü Dergisi-TAED 39-Prof. Dr. Hüseyin Ayan Özel Sayısı, Erzurum: s. 631- 650.

Tahir, B. M., (1333). Osmanlı müellifleri, 2, İstanbul.

Tatçı, M. ve Kurnaz, C. (1999). Kütahyalı bir gönül eri Çavdaroğlu Müftî Derviş, Ankara:

Tuman, N. (Yz.). “Askerî”, Tuhfe-i Nâ 'ilî, 2, 674- 675, 2864. Ankara.

Uraz, M. (1939). Türk Edip ve şâirleri, 1, İstanbul: Nümune Matbaası.

Ünver, İ., (1991). “Askerî”, Diyanet İslam Ansiklopedisi, 3, İstanbul.

Yavuz, A. F. (1975). (hzl.), Kur'ân-ı Kerîm ve Meâli Âlisi, İstanbul: Sönmez Yayınevi.

Yazıcıoğlu, F. (1995). "Muhammed Askerî (Güllaboğlu) hakkında inceleme”, IV. Afyonkarahisar Araştırmaları Sempozyumu Bildirileri, Afyonkarahisar: s. 265-273.

Yeniterzi, E. (1993). Divan şiirinde na't, Ankara: Türkiye Diyanet Vakfı Yayınları.

Yılmaz, M. (1992). Edebiyatımızda islamî kaynaklı sözler, İstanbul: Enderun Kitabevi.

ETİK ve BİLIMSEL İLKELER SORUMLULUK BEYANI

$\mathrm{Bu}$ çalışmanın tüm hazırlanma süreçlerinde etik kurallara ve bilimsel atıf gösterme ilkelerine riayet edildiğini yazar(lar) beyan eder. Aksi bir durumun tespiti halinde Afyon Kocatepe Üniversitesi Sosyal Bilimler Dergisi'nin hiçbir sorumluluğu olmayıp, tüm sorumluluk makale yazarlarına aittir.

\section{ARAŞTIRMACILARIN MAKALEYE KATKI ORANI BEYANI}

1. yazar katk1 oran1 : \%100 